\title{
THE IMPACT OF THE MONEY SUPPLY ON STOCK PRICES AND STOCK BUBBLES
}

\author{
Martin Širůček ${ }^{1}$ \\ ${ }^{1}$ Mendel University in Brno, Faculty for business and economics, Zemědělská 1, 61300 Brno \\ Email: sirucek@gmail.com
}

\begin{abstract}
This article is focused on the effect and implication of a change in the money supply for the US capital market. This market was chosen according to its part on the global market capitalization. Namely it is the Dow Jones Industrial Average (DJIA), which was chosen according to its long history, global sense and stabile construction. The money supply will be measured by the wider aggregate M2 and aggregate MZM (money with zero maturity). The goal of this paper is to detect, if the money supply influenced the stock indices in the years 1967 - 2011, if the impact of both money aggregates is nearly the same, and how the money supply influenced the bubble creation.
\end{abstract}

Keywords: co-integration, Granger causality, money supply, stock index, unit root test.

JEL classification: E51, G11, G12

Doručeno redakci: 29.6.2012; Recenzováno: 24.5.2013; 18.4.2013; Schváleno k publikování: 11.9.2013

\section{Introduction}

Shares and stock markets are extremely sensitive to any price-shaping information, relevant for future trends and market development. The price-shaping factors generally include macroeconomic and microeconomic factors, but also the psychological and subjective influence of investors who can affect the behaviour of the entire market and its volatility, the development of new technologies and the impacts of globalisation. A major role in the determination of share prices is held mostly by various macroeconomic factors, such as a change in interest rates, money supply, inflation, political shocks, legislation amendments, etc. Monetary policy represents one of the most efficient instruments of central banks in different countries. As shown below in more detail, many economists and scholars regard monetary policy as the most important macroeconomic policy instrument. This is why central banks apply these particular monetary policy instruments to influence real business and the economy as such. Therefore, it is essential to understand the effects of monetary policy and any changes thereto on the stock market as a vital determinant of economic development. The objective of this paper is therefore to find, describe and evaluate the effects of changes to the money supply on the US stock index. The sub-objectives are whether the effects of selected monetary aggregates on the stock index are the same or varied and whether there is a time delay in the response of a stock market to changed money supply.

\section{Literature review}

National stock markets, belonging to and being the basis of the global capital market, affect the global market on one hand, but on the other hand they are themselves under the influence of the global market. Some authors (Bilson, Brailsford, Hooper (2000)) note that national (risk) factors affect the performance of the stock market more than global factors (supranational). The basic instrument for investigating the factors affecting stock markets is the fundamental analysis which can be performed on three basic levels: global, sector-specific and corporate. Factors affecting the price behaviour not only of shares but also other securities and instruments can be further divided into macroeconomic and microeconomic (e.g. psychological effects). As King (1966) notes, stock markets are influenced by macroeconomic factors by an average of 50\%. A similar view is shared by Musílek (1997) 
who, unlike King, stays on the general level and claims that if an investor wants to be successful, he must focus mostly on price-shaping macroeconomic factors. In regard of that the spot price of stock present future income, which are discounted, Flannery, Protopapadakis (2002), mean that macroeconomic variables are the most important indicators, which influence the stock returns, because just these factors have an impact on future company's cash flow and influence the height of the discount rate.

The first study of modern history, which focuses on the effect of macroeconomic variables on stock prices was posted by e.g. Nelson (1976), Jaffe a Mandelker (1977) or Fama, Schwert (1977). The impact of national macro-economic factors on the performance of national stock market in the modern period was addressed by authors such as Bilson, Brailsford, Hooper (2000), who maintain that these factors determine the stock prices more than the global macroeconomic factors. According to Veselá (2010) the macroeconomic factors that influence the development of stock prices, include the interest rate, inflation, GDP, money supply, the movement of international capital changes in exchange rates, political and economic shocks. According to Kohout (2010), the most important factor influencing the development of stock prices in the long term is the amount of money in the economy (i.e. money supply). Also Flannery, Protopapadakis (2002) include the money supply, unemployment, trade balance, the number of new residential buildings and the Producer Price Index.

According to Maskay (2007) or Chromec (2006), the monetary policy or change in money supply, is one of the most effective tools available to the national central banks of individual countries in association with influencing the actual economic activity. Many authors, such as Keran (1971), Gupta (1974), Musílek (1997), Poiré (2000) or Shostack (2003) consider the money supply as the instrument of the monetary policy, to be the most important macroeconomic factor that influences the behaviour and the development of stock prices. Maskay (2007) and Ioannidis, Kontonikas (2006) consider the stock market to be the basic indicator of the condition and development of the economy strongly influencing and preceding it. These authors also consider the money supply to be a strong determinant of the stock market, i.e. of the entire economy. Money supply can affect stock prices directly, when there is more money in the economy than can be utilized so they are allocated to investments. But as already mentioned, for example, by using quantitative release results indirectly in the reduction of the interest rates rendering the external financing cheaper, leading to increasing investments (growth in the demand for shares) and consumption (better economic results of companies).

By examining global factors certain associations were discovered between variables (in this case the money supply) and the development of stock prices. By using these we can predict the future development and that represents an important guide for the investor. Most authors listing macroeconomic factors that influence the development of stock prices consider the monetary policy, or a change of the money supply in the economy to be the most important factor. A statement by Gupta (1974) serves as an example, when he says that the money supply can be utilised for predicting the development of stock markets. His investigation confirmed that $59 \%$ of the value of stock indices can be based on the money supply. This statement is supported by Rapach, Wohar, Rangvid (2005) who, in their analysis focused on the prediction of stock market development by using macroeconomic factors in 12 countries, concluded that the most trustworthy macroeconomic indicator for stock market predictions is the interest rate. Pearce, Roley (1985) in their research dealt with the issues of anticipative money supply and concluded that there is a reciprocal relation between the non-anticipative money supply and the development of the stock prices. On the contrary, according to 
Bernanke (2003) the anticipative change in the money supply will have no effect on the development of prices of financial assets (i.e. also including equity securities - shares) because the investors included it in their decisions (the asset prices were discounted). Only non-anticipative change in the money supply may influence the prices of securities. Varying effects of anticipative and non-anticipative money supply on the development of stock prices are confirmed by the Maskay (2007).

There were many studies published which dealt with the analysis of the influence of the money on the stock markets, albeit with differing results. As stated by Habibullah, Baharumshah (1996), the first author to empirically deal with the relationship between the money supply and stock rates was Sprinkel (1964), who found a strong relationship between the change in the U.S. money supply and stock prices in the observed period of 1918-1960. This study became the basis for the work of Mookerje (1987), Jeng, at al. (1990), and Malliaris, Urrutia (1991). In this respect, a question arises whether this relationship holds even today, that is approximately 50 years after publication of this "pioneering study", or how the massive change of the money supply (e.g. the consequences of quantitative release) during the recent financial crisis influenced the development of stock prices and how the change in the money supply affects the development of the stock price bubbles.

Other authors dealing with the correlation and link between stock markets and the money supply are e.g. Maysami, Koh (2000) who, in the conditions of the Asian market revealed a positive relationship between the money supply and the development of the SGX index (Singapore stock exchange), confirming the hypothesis that a growth in the money supply will cause inflation, which causes a growth in future cash-flow and share prices, as already investigated by Fama (1981). The same results confirm Maysami, Howe, Hamzah (2004), who discloses a positive dependence between money supply change and stock price evolution on Singapore stock exchange. The causality between the money supply and stock markets on emerging markets was investigated also by Brahmasrene, Jiranyakul (2007), specifically in their analysis of the Thai stock market between 1992 and 2003, where they found positive relations between money supply and stock prices. Cagli, Halac and Taskin (2010) dealt with the relationship between money supply and stock prices on another emerging market - the Turkish market. These authors did not confirm any co-integration between these variables. The effects of the changes in macroeconomic factors (including the money supply) on the development of stock prices were discussed also by Shaoping (2008), who confirmed a vary strong effect of the money supply on the development of stock prices in the period between 2005-2007. As stated, he found a long-term and stable relationship between stock prices and monetary aggregate M0, M1 and M2. Similarly, stock prices and money supply had a positive co-integration. The positive co-integration has thus resulted that the growth of money supply results in the rising prices of equity shares. The issues of efficiency of the stock market in Malaysia and co-integration between money supply and stock prices were discussed by Habibullah, Baharumshah (1996), who defined a weak efficiency and non-existent cointegration between the money supply and stock prices on this market. However, in a later study, Habibullah (1998), found a causal relationship between the money supply and stock prices. On the Japanese market, Kimura, Koruzomi (2003) discovered no relationship between the change in the money supply and the development of stock prices.

The positive relationship between macroeconomic indicators (including the money supply) is also demonstrated by Hanousek, Filler (2000) who confirmed a positive relationship between the money supply and stock prices in the conditions of Central Europe in 1993-1996. Positive correlation and causal relationship between the money supply and stock prices in the U.S. 
market have been shown in by Maskay (2007) and Flannery, Protopapadakis (2002), Poiré (2000) in their respective studies. As stated by Habibullah, Baharumshah (1996), in the conditions of the U.S. stock market there a positive influence of the money supply on the development of stock prices was found by Malliaris, Urrutia (1991), Mookerje (1987) and Jeng, et al. (1990).

As further stated by Husain, Mahmood (1999), Rozeff (1974) in his study revealed the effectiveness of the U.S. stock market in relation to the money supply, while Kraft, Kraft (1977) found no causal relationship between the equity returns and changes in the money supply on the same market.

Based on the review of literature resources, it can be concluded that among the different authors, there is inconsistency between the change in money supply and the development of stock markets - see for example the results of Habibullah, Baharumshah (1996) and Habibullah (1998). Moreover, according to the economic theory, there should be a causal relationship between the change in the money supply and the development of stock prices (see the next section), as discovered by some authors, but not by others, alternatively they discovered only a relationship between one of monetary aggregate and stock prices, but not in case of another one. Some authors suggest a strong link (Sprinkel (1964), Malliaris, Urrutia (1991), Jeng, et al. (1990)) and the relationship between the change in money supply and the development of stock prices. On the other hand, other authors (Kraft, Kraft (1977), Bianying (2004)), found no causal relationship. For example, Kulhanek, Matuzsek (2006) and Veselá (2007) identified a link between changes in the money supply and stock prices, but point out a gradual weakening of this link.

The money supply, as the most important macroeconomic factor that affects the stock prices is recognized by Maskay (2007), Dwyer, Hafer (1999), Sprinkel (1964), Poiére (2000), Musílek (1997), Kohout (2010), Nývltová, Režňáková ( 2007). According to Veselá (2007) the money supply also acts as the predicting indicator of the development of equity prices. There are several theoretical arguments supporting the assumption that the growth of the money supply increases the demand for stocks and hence their prices.

\section{Methodology}

For the empirical analysis are using moment time series of selected variable in monthly period from 1967 to 2011. Concretely the US stock market is represented by the Dow Jones Industrial Average index and money supply is represented by the monetary base M2 and MZM (money with zero maturity).

To eliminate statistically deviated results in the time line analysis, Tomšík, Viktorová (2005) recommend testing the stationarity and subsequently using only stationary time lines. According to Arlt (1997), there are several ways to determine the time line type, that is, to determine the time line co-integration order: (a) to examine the time line chart and evaluate subjectively whether the line is stationary or not, (b) to assess the shape of the autocorrelation function, (c) to apply the unit root test.

The test of unit root will be provide by the extended Dickey-Fuller test (ADF test) and KPSS test. According to Dickey, Fuller (1979), this test can be recorded in a general form:

$$
\Delta y_{t}=\beta_{0}+(\rho-1) y_{t-1}+\beta_{1} \Delta y_{t-1}+\beta_{3} \Delta y_{t-n}+\varepsilon_{t}
$$


After the ADF or KPSS, the Granger causality test will be performed, demonstrating the correlation or non-correlation between DJIA and the money supply. The point is that as Jochec (2010) notes, the Granger test assumes that all information for predicting selected variables is contained in the very past values of these variables.

The Granger causality test can be described through e.g. the following equations, verifying the causal relationship between a change in the money supply measured by the money supply (MS,) and the DJIA index:

$$
\begin{aligned}
& D J I A_{t}=\sum_{i=1}^{j} \alpha_{i} \cdot D J I A_{t-i}+\sum_{i=1}^{j} \beta_{i} \cdot M 2_{t-i}+\varepsilon \\
& M S_{t}=\sum_{i=1}^{j} \alpha_{i} \cdot M S_{t-i}+\sum_{i=1}^{j} \beta_{i} \cdot D J I A_{t-i}+\varepsilon
\end{aligned}
$$

The Granger test will be applied for the decision if the money supply is the most important factor, which evokes a stock bubbles too. Another way how to decide is to use a multiple regression model, which includes other macroeconomic variables. The multiple regression model can be specified as follows and it is a derivation from Kandir (2008):

$$
\Delta I=\beta_{0}+\beta_{1} \Delta I P I+\beta_{2} \Delta I R+\beta_{3} \Delta C P I+\beta_{4} \Delta O I L+\beta_{5} \Delta P P I+\beta_{6} \Delta U N+\beta_{7} \Delta M S+\varepsilon
$$

For empirical analysis the selected macroeconomic variable in formula (3) use $\Delta$ IPI as the change in industrial production indices, $\Delta$ IR as the change in interest rates (1 month time deposit rate), $\Delta \mathrm{CPI}$ as the change in inflation, $\Delta$ OIL asthe change in oil price (West Texas Intermediate), $\Delta$ PPI as the change in producers price indices, $\Delta U N$ as the change of unemployment, $\Delta \mathrm{MS}$ as the change in money supply (monetary base M2 and MZM), $\varepsilon$ represents the residual error.

\section{Results}

The initial analysis has revealed a strong trend of all considered variables, causing an apparent and serial correlation. Therefore the first differences of input variables were made, to eliminate autocorrelation and the variables thus achieved a stationary nature. After first differences were performed, the Durbin-Watson test was performed to determine the value of 1.89 for the first difference M2, and 1.90 for the MZM aggregate.

According to Pošta (2010) when estimating the regression model, an important role is played by the fact that the input variables were stationary. This is confirmed by Arlt (1997) and Kumar (2011), who argue that the implementation of the (equity) analysis requires only stationary time series. The fact that a stationary time series is involved can be detected by subjective assessment of time-series graphs, or through the use of expanded Dickey-Fuller (ADF) test or KPSS test.

Stationarity of time series is confirmed by the results of ADF unit root test, as in the table 1. Since the DJIA index level cannot reach negative values, the Dickey-Fuller unit root test is used in standard form with constant (4) and a constant and trend (5) with zero hypothesis $a=$ 1. The use of only stationary time series is recommended for example by Tomšík, Viktorová (2005) and Foresti (2007), who add that the ADF test is a very useful tool to test the unit root.

$$
\begin{gathered}
Y_{t}=b_{0}+(a-1) \cdot Y_{t-1}+\varepsilon \\
Y_{t}=b_{0}+b_{1} \cdot t+(a-1) \cdot Y_{t-1}+\varepsilon
\end{gathered}
$$


Table 1: ADF test, first differences

\begin{tabular}{|l|r|r|r|r|}
\hline \multirow{2}{*}{ d_DJIA } & \multicolumn{2}{|c|}{ a model with a constant } & \multicolumn{2}{c|}{ a model with a constant and trend } \\
\cline { 2 - 5 } & \multicolumn{1}{|c|}{ ADF statistic } & p-value & ADF statistic & \multicolumn{1}{c|}{ p-value } \\
\hline d_M2 & -21.7664 & $3.802 \times 10^{-38}$ & -21.8019 & $2.883 \times 10^{-50}$ \\
\hline d_MZM & -19.0674 & $5.58 \times 10^{-37}$ & -21.3193 & $1.521 \times 10^{-49}$ \\
\hline
\end{tabular}

Source: own research according to FED (2011), FRED (2012)

The results show that also on $1 \%$ significance level we can confirm, that these time series are stationary type $\mathrm{I}(0)$. But the executed KPSS test set first differences as non-stationary. According to this result it has to make second differences, which both tests set stationary.

As a part of the co-integration analysis the Engel-Granger test was used to confirm a longterm relationship between the money supply and the DJIA stock index. This confirms the unit root test regression relationship of residues whose values are given in the table 2 .

Table 2: Co-integration test

\begin{tabular}{|l|r|}
\hline \multicolumn{1}{|c|}{ dependent variable DJIA } & residual p-value \\
\hline Independent variable M2 (first difference) & $8.691 \times 10^{-46}$ \\
\hline Independent variable MZM (first difference) & $7.031 \times 10^{-46}$ \\
\hline dependent variable DJIA & residual p-value \\
\hline Independent variable M2 (second difference) & $8.798 \times 10-46$ \\
\hline Independent variable MZM (second difference) & $8.241 \times 10-46$ \\
\hline
\end{tabular}

Source: own research according to FED (2011), FRED (2012)

Table 2 shows that residuals are also on $1 \%$ significance level stationary and both time series are co-integrated, which is according to the economy theory.

To analyse the impact of the money supply on the DJIA stock market index a Granger test is used, as defined in the methodology (formula (2)). The set null hypothesis that money supply does not affect the DJIA stock market index will be validated on the basis of the Wald's Fstatistics, or p-values and their comparison with the level of significance. As stated by Baumöhl (2008), if the null hypothesis is rejected (at a given significance level) the variables are then considered in the regression equation as independent in the sense of Granger's causality.

As stated by Foresti (2007), in the implementation of Granger's causality test it is very important to choose the magnitude of delay. Similarly, Thornton, Batten (1984), also claimed that the result of Granger's test is very dependent on the length of delay. In the publications dealing with the choice of the length of the delay there is no consensus, some reports suggest that it is appropriate to use the minimum delays in the range of 1 to 6 . Other studies have considered this to be insufficient. For example Enders (1995) or Hamilton, Herrera (2000) suggest to apply a delay of 12 or more on the monthly data. On the other hand, Sewell (2001) states that the increasing delay results in the reduction of the validity of the test. Similarly, Urbain (1989) uses delays 1 and 6 in his analysis. The tests of the influence of money supply were performed with a delay of $1,2,3,4,5,6,12,18$, and 24 months.

Table 3 outlines the impact of delay duration on the results of the Granger's test, examining the effect of the changes in the money supply on the development of the DJIA stock market index, conducted at the $5 \%$ level of significance. 
Table 3: Granger causality test

\begin{tabular}{|c|c|c|c|c|c|c|c|c|c|}
\hline \multirow{2}{*}{$\begin{array}{c}\mathrm{H}_{0} \\
\alpha=5 \% \\
\end{array}$} & \multicolumn{9}{|c|}{ lag } \\
\hline & 1 & 2 & 3 & 4 & 5 & 6 & 12 & 18 & 24 \\
\hline the first difference & F-st. & F-st. & F-st. & F-st. & F-st. & F-st. & F-st. & F-st. & F-st. \\
\hline M2 doesn't cause DJIA & 1.4744 & 4.7768 & 3.1824 & 3.6787 & 3.3539 & 2.4995 & 1.6259 & 2.8925 & 3.3427 \\
\hline MZM doesn't cause DJIA & 0.1459 & 0.5573 & 0.5612 & 0.5468 & 1.3859 & 2.2601 & 3.0553 & 3.6735 & 3.9633 \\
\hline the second difference & & & & & & & & & \\
\hline M2 doesn’t cause DJIA & 9.4261 & 4.0999 & 5.6253 & 4.0460 & 3.2092 & 2.6255 & 1.8963 & 3.0705 & 3.5560 \\
\hline MZM doesn't cause DJIA & 0.6265 & 0.2821 & 0.9658 & 1.8402 & 2.7986 & 3.5374 & 3.0236 & 4.6682 & 3.9522 \\
\hline
\end{tabular}

Source: own research according to FED (2011), FRED (2012)

The achieved values confirm that when using first differences at the 5\% level of error probability, the money supply measured by M2 monetary aggregate, begins to affect the DJIA stock index with a delay of 2 months. Even though at a delay of 12 months, the null hypothesis of the Granger's test was not rejected. because the tested statistics was 0.145 lower than the critical value, in the terms of economic interpretation and really a minimum difference. I don't consider this to be significant.

In case of money aggregate MZM, the situation is completely different. In this case there is a demonstrable effect on the aggregate stock market only after certain time interval. Specifically, there is an evidence of an effect of this aggregate on the DJIA index only after application of 5 delays for the first differences, or 4 delays in the case of second differences. This result - as opposed to money aggregate M2, thus agrees with the above authors, who recommend the application of 12 delays as well as the described regarding changes in the money supply measured by MZM aggregate in the period of VI. 2008-VI. 2009, where the DJIA index responded with an approximately 10-month delay. Similar situation is found in relation to the use of the second differences of the MZM money aggregate, with the only difference being that there was a shift of the response of the stock index to change of the money supply by one month to respond and it begins to respond after 5-month delay.

In my opinion, the fact that first or second differences of the money supply are used is not so crucial in this case. Based on the results we can conclude that the influence of money supply measured by $\mathrm{M} 2$ on the DJIA index was demonstrated almost immediately with minimal delay, while the influence of monetary aggregate MZM was demonstrated with a time delay. From the perspective of the liquidity of individual aggregates, we can talk about surprising results, which should be exactly the opposite, i.e. the monetary aggregate M2 should show an effect after a time delay. In both aggregates the effect was demonstrated starting from a delay of 6 months, which is in a line with the results of the analysis of the American market between 2007 and 2011, when the DJIA index indeed reacted to the change in the money supply (regardless of the type of aggregate) with a delay of about half a year.

Based on the results, it can be concluded that according to the completed Engel-Granger test, there is a long-term relationship (co-integration) between the DJIA share index and the money supply as measured by M2 and MZM, whereas the M2 money aggregate has a faster effect on the stock market, especially in the short-term horizon of several months. This monetary aggregate begins to influence the DJIA stock market index with a delay of 1 to 2 months. In case of MZM money aggregate, its influence on the DJIA index was demonstrated only with a longer time delay. i.e. it influenced the DJIA index slowly.

When analysing the impact of money supply on stock bubble formation, and when verifying the hypotheses that the money supply is not the main determinant of stock price bubbles, it is 
first necessary to identify the stock price bubbles in the U.S. market, represented by the DJIA index. Throughout the observed period, several rises and subsequent drops can be identified on the market. From empirical viewpoint there is a problem to discover a bubble. or rather to determine what is and what is not a bubble. Kohout (2010) defines a bubble as the condition where there is an excessive growth for a period from 5 to 10 years before its burst. But the question remains, what is excessive. For empirical analysis, the recent sub-prime bubble was selected for the reasons of recency and general awareness.

Low interest rates were determined to be the main cause of this crisis, which enabled less sound clients to apply for mortgage loans, which they were unable to repay following the rise in interest rates. But the bubble but did not occur only in the real estate market, but also in the stock market, which grew steadily approximately until the second half of 2007. This rate of growth is approximately half of the average growth rate before the bubble burst in 1987 . The average monthly growth rate of the money supply over the same period amounted to $0.41 \%$ for the M2 aggregate. and $0.44 \%$ for aggregate MZM, which are values that are comparable to the growth rate of the money supply before 1987 .

Table 4: ADF test

\begin{tabular}{|l|r|r|r|r|}
\hline \multirow{2}{*}{} & \multicolumn{2}{|c|}{ a model with constant } & \multicolumn{2}{c|}{ a model with a constant and trend } \\
\cline { 2 - 5 } & ADF statistic & p-value & ADF statistic & p-value \\
\hline d_DJIA & -7.5490 & $2.966 \times 10^{-8}$ & -7.5238 & $2.713 \times 10^{-7}$ \\
\hline d_M2 & -7.9114 & $1.009 \times 10^{-8}$ & -7.9694 & $7.097 \times 10^{-8}$ \\
\hline d_MZM & -2.5725 & 0.1051 & -3.3605 & 0.0681 \\
\hline
\end{tabular}

Source: own research according to FED (2011), FRED (2012)

The p-value of the ADF test shows that first differences in monetary base MZM are not stationary, so we have to make second differences of this variable. All other variables are stationary yet by first differences.

Table 5 show the results of Granger test, which tested the impact of the money supply on stock indices DJIA on a $5 \%$ significance level, by several lags (because of a short time period, the maximum applicable lag is 12 ).

Table 5: Granger causality test, period 2004-2008

\begin{tabular}{|c|c|c|c|c|c|c|c|}
\hline \multirow{2}{*}{$\begin{array}{c}\mathrm{H}_{0} \\
\alpha=5 \%\end{array}$} & \multicolumn{7}{|c|}{ lag } \\
\hline & 1 & 2 & 3 & 4 & 5 & 6 & 12 \\
\hline the first/second difference & F-st. & F-st. & F-st. & F-st. & F-st. & F-st. & F-st. \\
\hline d_M2 doesn't cause DJIA & 2.9545 & 1.4031 & 0.8290 & 0.5693 & 0.3847 & 0.8235 & 3.0152 \\
\hline d_d_MZM doesn't cause DJIA & 7.0124 & 4.0595 & 3.2403 & 3.3431 & 2.5705 & 2.6293 & 1.6232 \\
\hline
\end{tabular}

Source: own research according to FED (2011), FRED (2012)

Based on the results of Granger's test it can be argued that in the period when the current financial crisis began to form, the money supply, measured by MZM aggregate affected the development of the DJIA index. The influence of the monetary aggregate M2 has been shown only when a delay of one year was applied. From this perspective it is an entirely different result than for the entire period, where the influence of the MZM aggregate on the DJIA index was demonstrated only when a longer delay - in the order of several months - was applied. A higher liquidity of this monetary aggregate is thus apparent in this period. This aggregate has greater effect than M2, especially thanks to the fact that in this period it reached higher values, accumulatively exceeding the volume of M2 aggregate. 
Based on the achieved results it can be concluded that the money supply measured by M2 monetary aggregate is not a significant factor in the development of the speculative bubble of 2007, while the money supply represented by the MZM aggregate is a major factor in the development of this bubble. To verify this statement, a multivariate regression analysis is used to confirm the importance of the MZM aggregate on the development of the stock bubble. Even before the actual analysis, individual time series of variables are presented that are used in the regression analysis. Their functional relationship with the dependent variable (DJIA) can be described as follows:

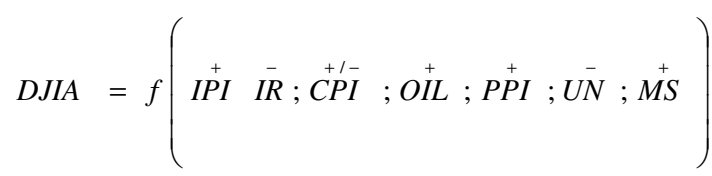

According to the formula (7) and (3) present the following tables 6 and 7 the results of the performed multivariate regression analysis, which was also performed on second difference values of the MZM money aggregate, which KPSS test set as stationary.

Table 6: OLS model, MS = M2

\begin{tabular}{|l|r|r|r|r|r|r|r|r|}
\hline \multicolumn{1}{|c|}{$\mathrm{R}^{2}=0,176$} & \multicolumn{1}{c|}{ constant } & \multicolumn{1}{c|}{ IPI } & \multicolumn{1}{c|}{ IR } & \multicolumn{1}{c|}{ CPI } & \multicolumn{1}{c|}{ OIL } & \multicolumn{1}{c|}{ PPI } & \multicolumn{1}{c|}{ UN } & M2 \\
\hline coefficient & 166.32 & -23.59 & -438.85 & -28.54 & -15.49 & -22.46 & -22.65 & 0.20 \\
\hline p-value & 0.005 & 0.21 & 0.19 & 0.82 & 0.17 & 0.65 & 0.85 & 0.84 \\
\hline
\end{tabular}

Source: own research according to FED (2011), FRED (2012)

Table 7: OLS model, MS = MZM

\begin{tabular}{|l|r|r|r|r|r|r|r|r|}
\hline $\mathrm{R}^{2}=0,195$ & \multicolumn{1}{c|}{ constant } & \multicolumn{1}{c|}{ IPI } & \multicolumn{1}{c|}{ IR } & \multicolumn{1}{c|}{ CPI } & \multicolumn{1}{c|}{ OIL } & \multicolumn{1}{c|}{ PPI } & \multicolumn{1}{c|}{ UN } & MZM \\
\hline coefficient & 112.56 & -20.20 & -189.66 & -34.51 & -17.79 & -18.28 & -24.66 & 1.42 \\
\hline p-value & 0.12 & 0.27 & 0.64 & 0.78 & 0.12 & 0.72 & 0.82 & 0.29 \\
\hline
\end{tabular}

Source: own research according to FED (2011), FRED (2012)

In a multivariate regression analysis, both models achieved comparable results again - in the case of the first model confirming the statistical insignificance of the monetary aggregate M2, which corresponds with the results of Granger test. It was in the case of the second model that showed apparent growth of the regression coefficient and reduction of the p-value compared to the money aggregate. Based on these results it is possible to conclude that the money supply, as measured by MZM money aggregate was an important factor in the development of the recent bubble in the stock market, represented by the DJIA index.

Based on the results of Granger test it can be argued that in the formation of the modern financial crisis between years 2004 and 2008, the money supply, measured by MZM aggregate had an effect on the change of the DJIA index. This is in accordance with the results achieved through the multidimensional regression analysis in which the lowest $\mathrm{p}$ values were measured for oil prices, industrial production index and the monetary aggregate MZM, while for M2 in the first model the p-value was equal to 0.84 demonstrating the statistical insignificance of this variable. From this perspective it can be argued that money supply measured by the monetary aggregate MZM was an important determinant of the modern stock bubble. Based on these results it can also be argued that the money supply as measured by MZM money aggregate is an important determinant of the development of the DJIA stock index, especially in the last 25 years, with the increase in market volume and volatility of the market, when the monetary aggregate appears to be statistically significant in explaining the development of the DJIA index during the Dot.com bubble formation. The use of the monetary aggregate (as well as the bubble of 2000) has lead to the increase in the 
determination index. To conclude this analysis, we provide the charts of the actual and balanced values using regression equation.

\section{Conclusion}

This paper dealt with the effects of the money supply on changes in the American stock index Dow Jones Industrial Average. The results of the performed Durbin-Wattson test demonstrated the auto-correlation of values. After that, the first differences of variables were performed, which appeared to be stationary using graphic analysis, with approximately zero mean and constant variance, a was confirmed by the results of ADF unit root test. To make sure we performed the KPSS test, which however, determined the first difference of the money supply to be non-stationary and therefore it was necessary to perform the second differences (differences of the first differences).

During the co-integration analysis the Engel-Granger test of residues was used to confirm a long-term relationship between the money supply and the DJIA stock index, where the differences between the money aggregates and their link to the DJIA index were minimal. After the demonstration of a long-term relationship between the money supply and the share index DJIA, this confirmed the hypothesis of the relationship between these variables. This was followed by the analysis of an impact of the money supply on the change of the DJIA index.

An analysis of the influence of changes in the money supply on the change of the stock index was performed using a dynamic model of the Granger test to verify the hypothesis that money supply does not affect the DJIA index. The Granger test, which was used to detect the effect of the money supply on the DJIA index, was used for the entire period, but also in subperiods, to demonstrate the influence of macroeconomic factors on the emergence of stock bubbles. For the entire observed period from 1967 to 2011, which included 530 monthly observations, the effect of the change of the money supply on the development of the DJIA index was confirmed for both monetary aggregates, pointing out the fact that an important role in this test is played by the applied length of delay. From the results it can be concluded that when applying a delay up to 6 months, the effect of the money supply measured through money aggregate M2 on the DJIA stock index was confirmed, while the effect of the MZM money aggregate on the stock prices can be demonstrated only with a delay of 6 or more months. The fact that for the entire period the effect of MZM on the DJIA was shown only with application of 6 (or 5-month delay for second differences), is in conflict with the assumption that this is a more liquid money aggregate, i.e. that the response of the stock market to changes of this aggregate should be faster. On the other hand, the graphical analysis confirmed that in the period VI.2008-VI.2009 the stock index responded to change in MZM money with approximately a 10-month delay.

The final part of the analysis attempted to determine whether the money supply is the main cause of the equity bubble or not. The period of analysis was the period of so-called subprime bubble, the burst of which had an effect not only on the American market but also resulted in a global fall of all stock markets. The bubble did not occur only in the real estate market but also in the stock market which grew steadily approximately until the second half of 2007 at the average monthly rate of $0.965 \%$ after three years of stagnation and a decline after the bursting of Dot-com bubble and after the attacks of September 11. This rate of growth is approximately half the average rate of growth before the bubble burst in 1987. The average monthly growth rate of money supply over the same period amounted to $0.41 \%$ for the M2 aggregate, and $0.44 \%$ for aggregate MZM, which are values comparable or even 
lower than the growth rate of money supply before 1987 and 2000. From this perspective it is beneficial to realize that while the stock index was growing at a relatively high rate throughout individual time periods when the bubble was formed, the money supply in all three bubbles was growing at approximately comparable rate. The completed Granger test demonstrated the effect of MZM aggregate - as opposed to money aggregate M2 on the formation of the recent price bubble in the stock market. This fact could be attributed to the situation that the money aggregate achieved higher accumulative growth in this period compared to M2. This means that the money supply measured by M2 monetary aggregate is not a significant factor in the development of the speculative bubble of 2007, while the money supply represented by the MZM aggregate is an important determinant of this bubble. This conclusion was confirmed by the performed regression analysis, in which approximately same values were found in both models, except for the money aggregates, where in case of MZM compared to M2, there was a growth of the regression coefficient and reduction of the pvalue. Based on the analysis of the bubbles it can also be argued that with the gradual growth of the market and its volatility the importance and impact of MZM monetary aggregate on the development of the DJIA index is growing.

\section{References}

[1] ARLT, J., 1997. Kointegrace v jednorovnicových modelech. Politická ekonomie [online]. 45(5), 733 - 746. [cit. $2^{\text {nd }}$ November 2011]. Accessible from:

http://nb.vse.cz/ arlt/publik/A_KJM_97.pdf

[2] BAUMÖHL, E., 2008. Skúmanie jednosmerných závislosti medzi svetovými akciovými indexmi. In: Národná a regionálná ekonomika VII. Bratislava: Ekonomická univerzita v Bratislavě. [cit. 20 ${ }^{\text {th }}$ May 2012]. Accessible from:

http://www3.ekf.tuke.sk/konfera2008/zbornik/files/abstrakty/baumohl_a.pdf

[3] BERNANKE, B., 2013. Monetary policy and the stock market. The Federal Reserve board. [online]. [cit. 27 $7^{\text {th }}$ March 2012]. Accessible from:

http://www.federalreserve.gov/boarddocs/speeches/2003/20031002/default.htm.

[4] BIANYING, X., 2004. Interaction of stock price of listed companies and macroeconomiy of China. Wuham University of science and technologies: Master's degree dissertation.

[5] BILSON, C. M., T. J. BRAILSFORD and V. J. HOOPER, 2000. Selecting marcoeconomic variables as explanatory factors of emerging stocks market returns. The Australian national university. Working papers series in finance 00-04.

[6] BRAHMASRENE, T. and K. JIRANYAKUL, 2007. Co-integration and causality between stock index and macroeconomic variables in a emerging markets. Academy of Acounting and Financial Studies Journal.

[7] CAGLI, E. C., U. HALC and D. TASKIN, 2010. Testing long run relationship between stock market and macroeconomic variables in the presence of structural breaks: The Turkish case. International research journal of finance and economics, 48. ISSN: 14502887.

[8] DICKEY, D. A. and W. A. FULLER, 1979. Distribution of the estimators for autoregressive time series with unit root test. Journal of the American statistical association, 366(74), 427 - 431. ISSN: 0162-1459. 
[9] DWYER, G. P. and R. W. HAFER, 1999. Are money growth and inflation still related?. Economic review. Federal reserve bank of Atlanta.

[10] ENDERS, W., 1995. Applied econometric time series. New York: John Wiley \& Sons.

[11] FAMA, E. F., 1981. Stock returns, real activity, inflation and money. The American Economic review, 71(4), 45-565.

[12] FAMA, E. F. and G. W. SCHWERT, 1977. Asset returns and inflation. Journal of financial economics, Vol. 5, 115-146. ISSN: 0304-405X.

[13] FEDERAL RESERVE SYSTEM (FED), 2011. Money stock measures. [online]. Boards of governors of the Federal reserve System [online]. [cit. $6^{\text {th }}$ October 2011]. Accessible from: http://www.federalreserve.gov/releases/h6/hist/h6hist1.txt

[14] FLANNERY, M. J. and A. PROTOPAPADAKIS, 2002 Macroeconomic factors do influence aggregate stock returns. The review of financial studies, 15(3), $751-782$. ISSN: 0893-9454.

[15] FORESTI, P., 2007. Testing for Granger causality between stock prices and economic growth. Munich personal RePEc archive, 2962(2007).

[16] FRED, 2012. Federal reserve bank of St. Louis [online]. [cit. 17 ${ }^{\text {th }}$ January 2012]. Accessible from: http://research.stlouisfed.org/fred2/graph/?id=BASE\#

[17] GUPTA, M. C., 1974. Money supply and stock market: A probabilistic approach. Journal of finance and quantitative analysis, 9(1). ISSN: 0022-1090.

[18] HABIBULLAH, M., 1998. Money, output, stock prices in Malaysia. Borneo review.

[19] HABIBULLAH, M. S. and A. Z. BAHARUMSHAH, 1996. Money, output and stock prices in Malaysia. International economic Journal [online]. 10(2), [cit. 11 ${ }^{\text {th }}$ January 2012]. Accessible from: http://147.46.167.195/ kiea/IEJ/vol10_2/Su7.pdf

[20] HAMILTON, J. D. and A. M. HERRERA, 2000. Oil shocks and aggregate macroeconomic behaviour. University of San Diego [online]. [cit. 16 ${ }^{\text {th }}$ May 2012]. Accessible from: http://dss.ucsd.edu/ jhamilto/bgwjun01.pdf

[21] HANOUSEK, J. and R. K. FILER, 2000. The relationship between economic factors and equity markets in Central Europe. Economics of transition, 8 (3), 623-638. ISSN: 1468-0351.

[22] HUSAIN, F. and T. MAHMOOD, 1999. Monetary expasion and stock returns in Pakistan. The Pakistan Development review, 769 - 776. ISBN: 969-461-065-6.

[23] CHROMEC, M., 2006. Dlouhodobé efekty monetární politiky: může ČNB ovlivnit ekonomický růst? Brno: Masarykova univerzita - Centrum výzkumu konkurenční schopnosti české ekonomiky [online]. [cit. $6^{\text {th }}$ December 2011]. ISSN: 1801-4496. Accessible from: http://is.muni.cz/do/1456/soubory/oddeleni/centrum/papers/wp200612.pdf

[24] IOANNIDIS, CH. and A. KONTONIKAS, 2006. The impact of monetary policy on stock prices. Journal of Policy Modeling, 30(1), 33-53. ISSN: 0161-8938.

[25] JAFFE, J. F. and G. MANDELKER, 1976. The Fisher effect for risky assets: An empirical investigation. The Journal of finance, 31(2), 447-458. ISSN: 1540-6261.

[26] JENG, C. C., J. S. BUTLER and J. T. LIU, 1990. The informational efficiency of the stock market: The international evidence of 1921 - 1930. Economics letter, 34(2), 157 162. ISSN: 0165-1765. 
[27] JOCHEC, L., 2010. Analýza závislostí ve vývoji akciových trhů a ekonomiky. Brno: Mendelova univerzita v Brně.

[28] KANDIR, S. Y., 2008. Macroeconomic variables, firm characteristic and stock returns: evidence from Turkey. International research journal of finance and economics, Issue 16. ISSN: $1450-2887$.

[29] KERAN, M. W., 1971. Expectations, money and the stock market. Federal reserve bank of St. Louis.

[30] KIMURA, T. and T. KORUZOMI, 2003. Optimal monetary policy in a micro-founded model with parametr uncertainty. Finance and economics discussiom series. Board of Governors of the Federal Reserve System (U.S.).

[31] KING, B., 1966. Market and industry factors in stock price behaviour. Journal of business, Vol. 39, 139 - 190. ISSN: 0021-9398.

[32] KOHOUT, P., 2010. Investiční strategie pro třetí tisíciletí. 6. vyd. Praha: Grada Publishing . ISBN: 978-80-247-3315-9.

[33] KRAFT, J. and A. KRAFT, 1977. Determinants of commonstock price: a time series analysis. The journal of finance, 32(2), 417 - 425. ISSN: 1540-6261.

[34] KULHÁNEK, L. a S. MATUZSEK, 2006. Peněžní zásoba a vývoj akciových trhů v České republice, Slovenské republice a ve vybraných zemích. In: Mezinárodní vědecká konference Národohospodárskej fakulty Ekonomické univerzity v Bratislavě „Znalostná ekonomika - nové výzvy pre nárohospodársku vedu“. Bratislava: Ekonomická univerzita v Bratislavě.

[35] KUMAR, A., 2011. An empirical analysis of causal relationship between stock market and macroeconomic variables in India. International Journal of Computer Science \& Management Studies, 11(01). ISSN: 2231-5268.

[36] MALLIARIS, A. G. and J. L. URRUTIA, 1991. An empirical investigation among real monetary and financial variables. Economics letter, 37(2), 151-158. ISSN: 0165-1765.

[37] MASKAY, B., 2007. Analyzing the Effect of Change in Money Supply on Stock Prices, The Park Place Economist, 15(1), 72 - 79. ISSN: 0736-8631.

[38] MAYSAMI, R. C. and T. S. KOH, 2000. A Vector Error Correction Model of the Singapore Stock Market. International Review of Economics and Finance, 9(1), 79 - 96. ISSN: 1059-0560.

[39] MAYSAMI, R. C., L. C. HOWE and M. A. HAMZAH, 2004. Relationship between mocroeconomic variables and stock market indices: cointegration evidence from stock exchange of Singapore's all-s sector indices. JournalPengurusan, [online]. [cit. 15 January 2012]. Accessible from: http://www.ukm.my/penerbit/jurnal_pdf/Jp24-03.pdf

[40] MOOKERJE, R., 1987. Monetary policy and the information efficiency of the stock market: The evidence from many countries. Applied economics, 19(1), 1521 - 1532. ISSN: $1521-1532$.

[41] MUSÍLEK, P. Změny makroekonomických veličin a akciové kurzy. Finance a úvěr, 47(3), 150 - 162. ISSN: 0015-1920.

[42] NELSON, C. R., 1976. Inflation and the rates of return on common sock. Journal of finance, 31(2), 471 - 483. ISSN: 1540-6261. 
[43] NÝVLTOVÁ, R. a M. REŽŇÁKOVÁ, 2007. Mezinárodní kapitálové trhy: zdroj financování. 1. vyd. Praha: Grada Publishing, a.s. ISBN: 978-80-247-1922-1.

[44] PEARCE, D. K. and V. V. ROLEY, 1985. Stock prices and economic news. The journal of business, 58(1), 49 - 67. ISSN: 1573-0697.

[45] POIRÉ, N. P., 2000. The money effect. Barron's business and financial weekly magazine.

[46] POŠTA, V., 2010. Role fundamentálních faktorů při analýze chování Pražské burzy [online]. Praha: Vysoká škola ekonomická, [cit. 30 ${ }^{\text {th }}$ November 2011]. Accessible from: www.vse.cz/polek/download.php?jnl=eam\&pdf=74.pdf

[47] RAPACH, D. E., M. E. WOHAR and J. RANGVID, 2005. Macro variables and international stock return predictability. International journal of forecasting, 21(1), 137 - 166. ISSN: 0169-2070.

[48] ROZEFF, M. S., 1974. Money and stock prices, Market efficiency and the lag in effect of monetary policy. Journal of Financial Economics, 1(3), 245 - 302. ISSN: 0304$405 X$.

[49] SEWELL, M., 2001. Longitudinal data analysis.[online]. Cambridge, [cit. $14^{\text {th }}$ Juny 2012]. Accessible from: http://martinsewell.com/causality/Zorn01.pdf

[50] SHAOPING, CH., 2008. Positivist analysis on effect of monetary policy on stock price behaviours. In: Conference on regional economy and sustainable development, 2008. ISBN 978-0-646-50352-3.

[51] SHOSTACK, F., 2003. Making sense of money supply data. [online]. [cit. $13^{\text {th }}$ May 2011]. Accessible from:

http://www.wissensnavigator.com/documents/MoneySupplyShostak.pdf

[52] SPRINKEL, B., 1967. Money and stock prices. Illinois: Richard D Irwin. ISBN: 9780256005134.

[53] THORNTON, D. L. and D. S. BATTEN, 1984. Lag length selection and Granger causality [online]. Federal reserve bank of St. Louis, Working paper 1984-001 A. [cit. $4^{\text {th }}$ Juny 2012]. Accessible from: http://research.stlouisfed.org/wp/1984/1984-001.pdf

[54] TOMŠÍK, V. a D. VIKTOROVÁ, 2005. Peníze a hospodářský růst v české republice je mezi nimi vztah? [online]. Praha: Vysoká škola ekonomická, [cit. 2ns November 2011]. Accessible from: http://panda.hyperlink.cz/cestapdf/pdf05c4/tomsik.pdf

[55] URBAIN, J. P., 1989. Model selection criteria and Granger causality test. University of Liége, Holland , 1989. Economics Letter, 29(4), 317 - 320, ISSN: 0165-1765.

[56] VESELÁ, J., 2007. Investovaní na kapitálových trzích. Praha: ASPI, a. s. ISBN: 97880-7357-297-6.

[57] VESELÁ, J., 2010. Český kapitálový trh pohledem globální fundamentální analýzy. In: Evropské finanční systémy 2010. Brno: Masarykova univerzita. ISBN: 978-80-2105182-9. 